\title{
Avaliação de diferentes condições metodológicas para aumentar a sensibilidade no diagnóstico molecular de Bartonella spp..
}

\section{Beatriz Andrade*, Ana Paula R. Santos, Amanda R. Almeida, Paulo E. N. F. Velho.}

\section{Resumo}

As bartoneloses são doenças causadas pelas Bartonella spp., bactérias emergentes e negligenciadas, potencialmente fatais. Sua bacteremia é baixa, dificultando seu diagnóstico e exigindo a realização de diferentes técnicas para diminuir resultados falso-negativos. Ainda não existe um método padrão-ouro para o diagnóstico. Sendo assim, este trabalho tem o objetivo de comparar entre métodos de extração de DNA, aquele com maior eficácia na quantidade e qualidade do DNA extraído, visando a redução de resultados falso-negativos e a viabilidade da metodologia na rotina diagnóstica.

Palavras-chave: Bartonella, sensibilidade, diagnóstico

\section{Introdução}

As bartoneloses causam uma grande variedade de manifestações clínicas, dentre elas fadiga, eritema nodoso, febre de origem indeterminada e recorrente, indisposição, insônia, depressão, adenopatia, linfadenopatia, esplenomegalia, angiomatose bacilar, hepatite, manifestações dermatológicas como exantemas, púrpuras, eritema nodoso e polimorfo, granuloma anular, eritema multiforme, púrpura trombocitopénica, entre diversas outras manifestações. Apesar dos sintomas serem muito variados, a infecção pode ser assintomática ou subclínica. Essa diversidade nas manifestações causadas pelas Bartonella spp. está ligada a vários fatores, como a resposta imunológica do paciente, a variedade de espécies e cepas e sua virulência. Algumas dessas manifestações podem vir a ser fatais, especialmente em indivíduos imunodeprimidos (KAISER et al., 2011). As Bartonella spp. apresentam uma distribuição universal e negligenciada, sua detecção é extremamente difícil e seu crescimento fastidioso faz com que inúmeros pacientes fiquem sem 0 diagnóstico (VELHO et al., 2003). Atualmente a detecção é realizada com o uso concomitante de diferentes métodos moleculares, porém, tais procedimentos demandam muito tempo e altos custos, impossibilitando a aplicabilidade da detecção na rotina clínica. Sendo assim, este trabalho tem o objetivo de investigar dentre dois métodos de extração de DNA aquele que possibilite maior quantidade $e$ qualidade de DNA extraído contribuído para um aumento na sensibilidade dos testes moleculares e consequentemente diminuir os resultados falso-negativos, tornando o diagnóstico mais sensível.

\section{Resultados Parciais e Discussão}

Figura 1.Fluxo experimental.

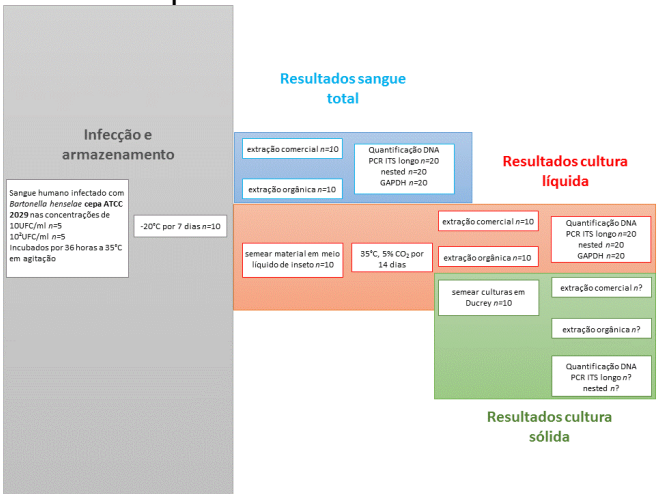

Tabela 1. Quantificação do DNA.

\begin{tabular}{|l|l|l|} 
Método & \multicolumn{1}{c}{$\begin{array}{c}\text { Média da Concentração } \\
\mu \mathrm{g} / \mu \mathrm{l}\end{array}$} & $\begin{array}{c}\text { Média Razão } \\
260 / 280 \mathrm{~nm}\end{array}$ \\
\hline Comercial & 0,03 & 1,74 \\
\hline Orgânica & 0,12 & 1,50 \\
\hline teste $\boldsymbol{t}$ & $\boldsymbol{p}<\mathbf{0 , 0 1}$ & $\boldsymbol{p}<\mathbf{0 , 0 0 1}$ \\
\hline
\end{tabular}

Entre os protocolos avaliados, a extração orgânica proporciona uma maior quantidade de DNA, quando comparada com a extração comercial. Contudo a avaliação da razão 260/280nm, não foi diferente entre os métodos.

\section{Conclusões}

Até o presente momento a extração orgânica é mais eficiente quanto a quantidade de DNA extraído. Porém a razão 260/280nm não é satisfatória, mostrando contaminações com proteínas, gorduras e resquícios dos reagentes utilizados no processo de extração.

Kaiser PO, Riess T, O\&\#39;Rourke F, Linke D, Kempf VA. Bartonella spp. throwing light on uncommon human infections. International journal of medical microbiology : IJMM. [Research Support, Non-U.S. Gov\&\#39;t Review]. 2011 Jan;301(1):7-15.

Velho PE, Cintra ML, Uthida-Tanaka AM, de Moraes AM, Mariotto A. What do we (not)know about the human bartonelloses? Braz J Infect Dis 2003; 7:1-6. 1986, 108,3335 . 